\title{
What's in a name? Problems, facts and controversies regarding neurological eponyms
} O que significa um nome? Problemas, fatos e controvérsias de epônimos em neurologia Hélio A. G. Teive1, Plínio M. G. Lima1', Francisco M. B. Germiniani1, Renato P. Munhoz²

\begin{abstract}
The use of eponyms in neurology remains controversial, and important questions have been raised about their appropriateness. Different approaches have been taken, with some eponyms being excluded, others replaced, and new ones being created. An example is Hallervorden-Spatz syndrome, which has been replaced by neurodegeneration with brain iron accuulatium (NBIA). Amiothoplic lateral sclerosys (ALS), for which the eponym is Charcot's disease, has been replaced in the USA by Lou Gehrig's disease. Guillain-Barré syndrome (GBS) is an eponym that is still the subject of controversy, and various different names are associated with it. Finally,restless legs syndrome (RLS), which was for years known as Ekbom's syndrome, has been rechristened as RLS/Willis-Ekbom syndrome.
\end{abstract}

Keywords: neurology; eponyms; history of neurology.

\section{RESUMO}

O uso de epônimos em neurologia permanece ainda controverso nos dias de hoje, e importantes questões tem sido levantadas sobre o seu uso. Diferentes abordagens têm sido feitas, com a exclusão de alguns epônimos, modificação ou criação de outros. Um exemplo é a síndrome de Hallervorden-Spatz (SHS), cuja denominação foi modificada para neurodegeneração associada com acúmulo de ferro cerebral (NBIA). Outro exemplo é a esclerose lateral amiotrófica (ELA), cujo epônimo doença de Charcot, tem sido substituído nos EUA por doença de Lou Gehring. A síndrome de Guillain-Barré (SGB) representa um epônimo em que a controvérsia persiste, e diferentes nomes têm sido associados ao clássico SGB. Por fim, a síndrome das pernas inquietas (SPI), que por anos foi definida como síndrome de Ekbom, e que na atualidade foi definida como SPI/síndrome de Willis-Ekbom.

Palavras-chave: neurologia; epônimos; história da neurologia.

The use of eponyms in neurology reached its peak at the end of the $19^{\text {th }}$ century and the beginning of the $20^{\text {stl }}$ to the point that many diseases are known worldwide by their eponyms, such as Alzheimer's disease, Parkinson's disease and Wilson's disease ${ }^{1,2}$. However, in the last decades of the $20^{\text {th }}$ century, the use of eponyms for neurological diseases increasingly gave way to the use of more scientific names and acronyms, such as restless legs syndrome (RLS), acute inflammatory demyelinating polyradiculoneuropathy (AIDP) and amyotrophic lateral sclerosis (ALS). Curiously, in recent years the situation has changed dramatically and certain eponyms have been abandoned for a variety of reasons while others have been kept or even changed, not without a certain amount of surrounding controversy ${ }^{1,2}$. The present review addresses this issue and how it impacts in the current branding of RLS, ALS, neurodegeneration with brain iron accumulation (NBIA) and Guillain-Barré syndrome (GBS).

\section{RESTLESS LEGS SYNDROME/WILLIS-EKBOM DISEASE}

RLS was first described in 1685 by Sir Thomas Willis, but other researchers, including Huss and Wittmaack, have since made significant contributions to the study of this disease ${ }^{3}$. However, the most significant contribution was the description by professor Karl Ekbom, who published two classic articles in 1944 and 1945, most notably the latter ${ }^{3}$. After various studies on RLS were published by Ekbom, the disease became known around the world as Ekbom's syndrome ${ }^{3}$, but at the end of the last century, this eponym fell into increasing disuse and the term RLS was commonly used ${ }^{3}$. In 2013, the International Restless Legs Syndrome Study Group suggested that the name of the disease should be changed to an amalgamated form, RLS/Willis-Ekbom disease, as a tribute to the first person to ever study it (Thomas Willis) and the first detailed clinical

'Universidade Federal do Paraná, Hospital de Clínicas, Serviço de Neurologia, Curitiba PR, Brasil;

${ }^{2}$ University of Toronto, Toronto Western Hospital, Morton and Gloria Shulman Movement Disorders Centre, Toronto, Canadá.

Correspondence: Dr. Hélio A. G. Teive; Rua General Carneiro 1103/102; 80060-150 Curitiba PR, Brasil; E-mail: hagteive@mps.com.br

Conflict of interest: There is no conflict of interest to declare.

Received 15 January 2016; Accepted 10 February 2016. 
description of the disease by Karl Ekbom ${ }^{4}$. Accordingly, in 2014 the revised diagnostic criteria for Restless legs syndrome/Willis-Ekbom disease were published ${ }^{4}$.

\section{NEURODEGENERATION WITH BRAIN IRON ACCUMULATION}

Neurodegeneration with brain iron accumulation (NBIA) represents a heterogeneous group of inherited neurodegenerative diseases characterized by excess iron accumulation, particularly in the basal ganglia and to a lesser degree in the substantia nigra and adjacent regions ${ }^{5}$. Common clinical features of NBIA include movement disorders, particularly parkinsonism and dystonia, cognitive dysfunction, pyramidal signs and retinal abnormalities ${ }^{5}$. In 1922, Hallervorden and Spatz reported the case of a family with five affected sisters with dystonia, cognitive dysfunction and confirmed neuropathological lesions of the globus pallidus and substantia nigra ${ }^{5,6}$. After this kindred-case description, the disease became known around the world as Hallervorden-Spatz syndrome (HSS) ${ }^{5,6}$. But, in spite of their seminal description, a shadowy past would lead to a change in nomenclature for this syndrome: Julius Hallervorden and Hugo Spatz were important German neuropathologists who performed several neuropathological studies on brain specimens of individuals with mental retardation executed during the Third Reich euthanasia program ${ }^{5,6}$. After confirmation of Hallervorden's and Spatz's involvement in the euthanasia program operated by the Nazi regime in Germany and recent neuroimaging and genetic discoveries, this syndrome was renamed NBIA ${ }^{5,6}$. To date, ten forms of NBIA have been described, the most common of which are pantothenate kinase-associated neurodegeneration (PKAN), caused by mutations in the PANK2 gene ${ }^{5}$.

\section{GUILLAIN-BARRÉ SYNDROME}

Guillain-Barré syndrome (GBS) was first described in 1916 by George Guillain, Jean-Alexandre Barré and André Strohl' ${ }^{7}$. The disease is a form of acute autoimmune polyradiculoneuropathy. A characteristic finding is albuminocytological dissociation in the cerebrospinal fluid, and the clinical presentation is typically an ascending flaccid paralysis with loss of deep tendon reflexes ${ }^{7}$. The eponym GBS has been the subject of continual discussion since the early $20^{\text {th }}$ century and different opinions and suggestions have been put forward regarding alternative eponyms. Some authors suggest that the eponym Guillain-Barré-Strohl should be used because of André Strohl's important contribution to the electrophysiology studies required to investigate this condition? while others suggest that the name of Octave Landry, who described the syndrome as "acute ascending paralysis" in 1859, should be included in the eponym. In 1876, the disease became known as "Landry (ascending) paralysis", and after 1956 it was known as "Landry-Guillain-Barré syndrome" or even "Landry-Guillain-Barré-Strohl syndrome" ${ }^{\text {"7.8 }}$. Other authors proposed the name "Wardrop-Guillain-Barré-Landry-Strohl" because of the description of cases of rapidly progressive paralysis and other features of GBS by James Wardrop and Charles-Prosper Ollivier?. Currently, the traditional form GBS is the most widely used eponym, together with the descriptive names acute inflammatory demyelinating polyneuropathy and acute inflammatory demyelinating polyradiculoneuropathy.

\section{AMYOTROPHIC LATERAL SCLEROSIS (ALS)}

ALS is a fatal neurodegenerative disease first described in the 19th century by Salpêtrière school's most famous professor, Jean-Martin Charcot, considered the father of neurology9. Charcot described the disease in 1874 after reporting various forms of the condition in detail and called it amyotrophic lateral sclerosis ${ }^{9,10}$. This was undoubtedly one of Charcot's greatest contributions to neurology. Ever since the disease has become known as Charcot's disease, particularly in Europe. However, in some places, especially the USA, the condition is known as Lou Gehrig's disease, in memory of the famous American baseball player who died 74 years ago and allegedly suffered from the condition'. While this is a popular eponym for ALS in the USA, Charcot's contribution to the definition of the disease remains paramount and, above all, the eponym "Charcot's disease" must not be forgotten.

\section{FINAL REMARKS}

The use of eponyms in Neurology remains controversial to this day and a matter of much debate. What can be observed in recent years is that the factors governing whether certain neurologic eponyms are used, changed or excluded vary widely, often due to political factors. For example, despite Hallervorden's and Spatz's original scientific contribution, the eponym Hallervorden-Spatz syndrome was replaced by NBIA because of their past as Nazi criminals. Another eponym, Charcot's disease, has been forgotten or replaced by ALS, or Lou Gehrig's disease. The eponym GBS is still the subject of controversy, and various names have been suggested that could be used in variations of the classical form. Finally, RLS, which for several years had been known as Ekbom's syndrome and then RLS, was recently defined as an amalgamated form - RLS/Willis-Ekbom syndrome ${ }^{4,6,7,9}$. 
1. Okun MS. Neurological eponyms: who gets the credit? Essay review. J Hist Neurosci. 2003;12(1):91-103. doi:10.1076/jhin.12.1.91.13779

2. Macaskill MR, Anderson TJ. Whose name is it anyway? Varying patterns of possessive usage in eponymous neurodegenerative diseases. PeerJ. 2013;1:e67. doi:10.7717/peerj.67

3. Teive HAG, Munhoz RP, Barbosa ER. Professor Karl-Axel Ekbom and restless legs syndrome. Parkinsonism Relat Disord. 2009;15(4):254-7. doi:10.1016/j.parkreldis.2008.07.011

4. Garcia-Borreguero D, Kohnen R, Silber MH, Winkelman JW, Earley CJ, Högl B et al. The long-term treatment of restless legs syndrome/Willis-Ekbom disease: evidence-based guidelines and clinical consensus best practice guidance: a report from the International Restless Legs Syndrome Study Group. Sleep Med. 2013/14;14(7):675-84. doi:10.1016/j.sleep.2013.05.016
5.

Hogarth P. Neurodegeneration with brain iron accumulation: diagnosis and management.J. Mov Disord. 2015;8(1):1-13. doi:10.14802/jmd.14034

6. Shevell M. The declining use of the Hallervorden-Spatz eponym. J Child Neurol. 2012;27(10):1308-9. doi:10.1177/0883073812454575

7. Wijdicks EF, Ropper AH. The Guillain-Barré syndrome. In: Koehler PJ, Bruyn GW, Pearce JMS. Neurological eponyms. Oxford: Oxford University Press; 2000. p. 219-26.

8. King EG, Jacobs H. "Complications" of the Landry-Guillain-Barré-Strohl syndrome. Can Med Assoc J. 1971;104(5):393-8.

9. Goetz CG. Charcot's disease: amyotrophic lateral sclerosis. In: Koehler PJ, Bruyn GW, Pearce JMS. Neurological eponyms. Oxford: Oxford University Press; 2000. p. 269-76.

10. Charcot JM. Lecture XIII. On amyotrophic lateral sclerosis. Symptomatology. In: Sigerson G. Lectures on the diseases of the nervous system. New York: Hafner; 1962. p. 192-204. 